\title{
A review of potential methods for monitoring rangeland degradation in Libya
}

\author{
Abdulsalam Al-bukhari ${ }^{1,2}$, Stephen Hallett ${ }^{1 *}$ and Tim Brewer $^{1}$
}

\begin{abstract}
Natural and human factors exert a profound impact on the degradation of rangelands, human effects being the most significant factor in increasing the severity of deterioration. This occurs through agricultural expansion at the expense of rangelands, and with the number of domestic and wildlife animals exceeding the natural carrying capacity. This raises concerns about the ongoing sustainability of these land resources, as well as the sustainability of traditional pastoral land practices. Rangelands require effective management, which is dependent upon accurate and timely monitoring data to support the assessment of rangeland deterioration. Natural rangelands provide one of the significant pillars of support for the Libyan national economy. Despite the important role of rangeland in Libya from both economic and environmental perspectives, the vegetation cover of Libyan rangeland has changed adversely qualitatively and quantitatively over the past four decades.

Ground-based observation methods are widely used to assess rangeland degradation in Libya. However, multi-temporal observations are often not integrated nor repeatable, making it difficult for rangeland managers to detect degradation consistently. Field study costs are also significantly high in comparison with their accuracy and reliability, both in terms of the time and resources required. Remote-sensing approaches offer the advantage of spanning large geographical areas with multiple spatial, spectral and temporal resolutions. These data can play a significant role in rangeland monitoring, permitting observation, monitoring and prediction of vegetation changes, productivity assessment, fire extent, vegetation and soil moisture measurement and quantifying the proliferation of invasive plant species. This paper reviews the factors causing rangeland degradation in Libya, identifying appropriate remote-sensing methods that can be used to implement appropriate monitoring procedures.
\end{abstract}

Keywords: Libyan rangeland, Land degradation indicators, Rangeland monitoring, Rangeland management, Remote-sensing data

\section{Introduction}

Substantial increases in the world's population over the past 50 years have led to extensive overuse of natural resources, with consequent and serious environmental impacts (UN DESA 2015). One principal concern is the growing and extensive abuse of rangelands in many arid and semi-arid regions of the world. Rangelands are defined as those parts of the world where domestic animals and wildlife graze on native vegetation (Squires 2010), and cover $40-50 \%$ of the global land area (Mitchell 2000).

\footnotetext{
* Correspondence: s.hallett@cranfield.ac.uk

'School of Water, Energy and Environment, Cranfield University, Bedford MK43 OAL, UK

Full list of author information is available at the end of the article
}

These areas provide essential forage for animals and a habitat for wildlife in many places globally (Yu et al. 2010). Many human communities live in and depend directly upon rangelands for their livelihood, whereas others rely on the rangelands for recreation and for its spiritual and cultural values (Maczko et al. 2011). Rangelands support both those living within them and those beyond (AU-IBAR 2012). It is estimated that rangelands store up to $30 \%$ of the world's soil carbon, in addition to the substantial amount of above-ground carbon stored in trees, bushes, shrubs and grasses (Neely et al. 2009). As ecosystems become degraded, their capacity to deliver such services become undermined (Favretto et al. 2016). The capacity of rangelands as a feed source for livestock and the support of 
sustainable livelihoods for herders has been reduced due to the combination of various factors, including degradation due to overgrazing and expansion of cultivation (Bounejmate et al. 2004). The primary force driving rangeland degradation is often attributed to anthropogenic influences, e.g. overgrazing and mismanagement of resources by pastoralists (WISP 2008; Li et al. 2013; Sidahmed and Yazman 1994; Squires 2010). The degradation of biophysical rangeland resources has serious implications for pastoral ecosystems, livelihoods and livestock production (AU-IBAR 2012). Squires (2010) states that many land-use strategies and methods are no longer suitable in the face of economic and political changes, due to population growth and the trend for nomadic pastoralists to become sedentary. Rangeland degradation has become a significant challenge in North Africa due to its impact on the spatial extent of the rangelands and their productivity (Dutilly-Diane 2007) and in Libya this situation was recognised by Dregne and Chou (1992) where two thirds of the rangeland were categorised as degraded.

Libyan rangelands are one of the significant pillars of support for the Libyan national economy. Libyan rangelands occupy about 13.3 million hectares, extending across more than $70 \%$ of the land area of the country. They are distributed across four regions according to the classification of the Development Commission of Rangeland (1980): the western, central and eastern regions, located above the $50-\mathrm{mm}$ isohyet, and the southern region, located below the $50-\mathrm{mm}$ isohyet (Figure 1).

These areas play an important role in protecting the environment and conserving the soil from erosion by water and wind, which is reflected in the impact reduction of desertification factors. They are also important as a recreational resource, providing an important source of firewood, aromatic and medicinal plants as well as non-traditional food. Moreover, a large number of people in Libya work in sectors related to rangeland (Omar Al-Mukhtar University 2005). The Libyan rangeland contributes an important role towards the food needs of the large numbers of grazing animals, whose total annual food requirement is estimated to be some 562 thousand tons (Rangeland Development Project 2008). The rangeland also contains the largest soil seed banks amongst Libyan rangelands (El-Barasi and Saaed 2013).

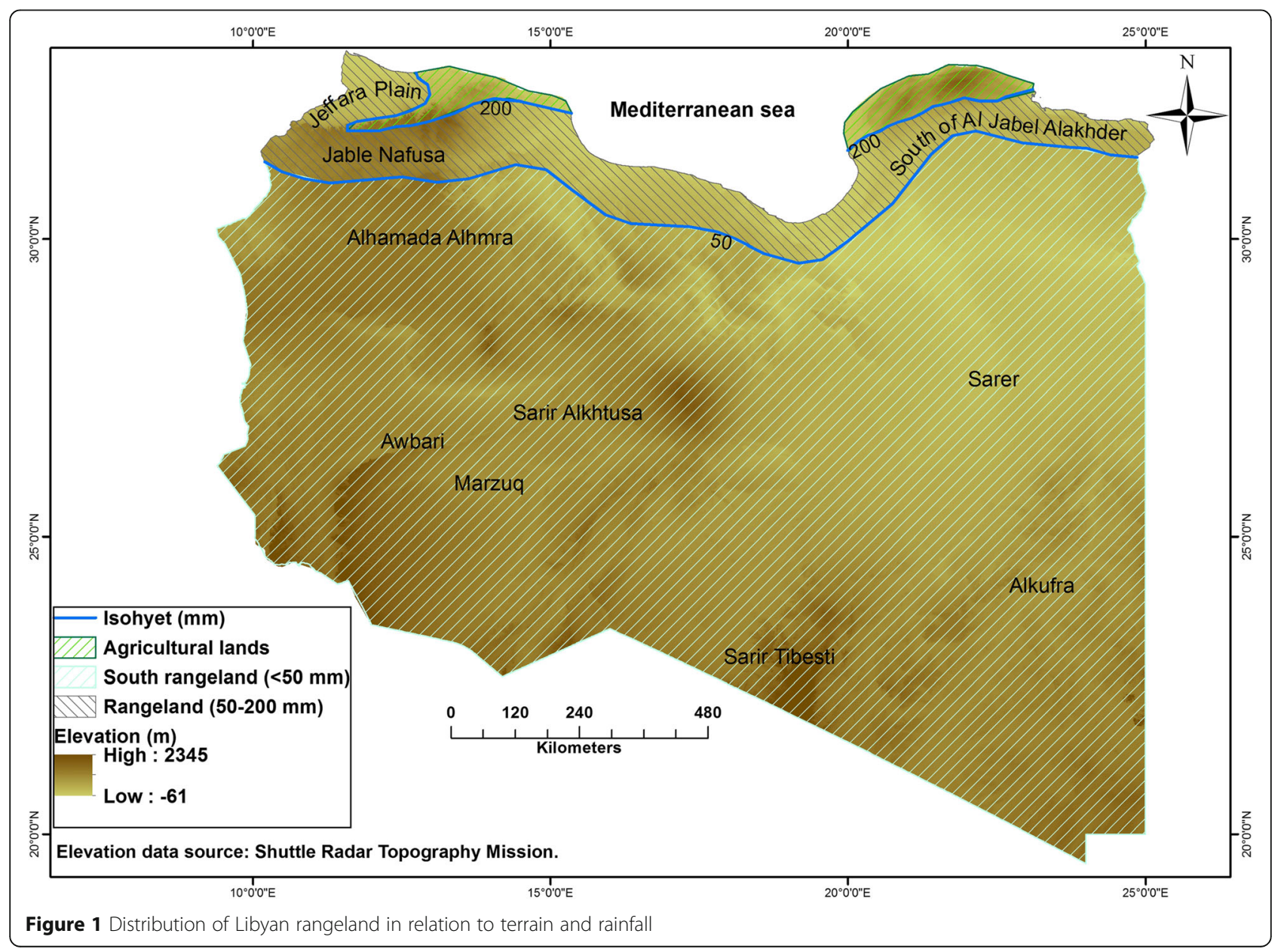


However, the vegetation cover in Libyan rangeland has changed both qualitatively and quantitatively over the past four decades as a result of many factors including low rainfall, overgrazing, improper agricultural practices, mismanagement, misuse, seasonal fire outbreaks, frequent droughts, wind and water erosion and human activities (Darag and Yousif 1996; Omar Al Mukhtar University 2005). This paper reviews the factors causing degradation in Libyan rangel and identifies remote-sensing methods that can be used as part of a monitoring programme.

\section{Rangeland degradation}

Rangeland degradation has an impact on biotic sustainability and reduces the variety of future uses of rangeland ecosystems (Kauffman et al. 1997). Decisions taken about land use, the number of livestock species to use, the season of use and stocking density all have profound and far-reaching effects on the stability and, ultimately, the sustainable use of rangelands (Squires 2010). Rangeland degradation may be defined as "the retrogression of vegetative cover leading to surface layer exposure to wind and soil erosion by washing away the organic compositions that give vigour to plants' development" (Solomon 2003), arising as a consequence of excessive human activities and/or unfavourable natural conditions. Rangeland degradation represents more than the retreat of vegetative cover. It includes a change in species composition, a loss of range biodiversity, reduction in biomass production and the presence of soil erosion (Ahmad and Ehsan 2012). This has been caused predominantly by the continued and rapid increase in human and livestock populations and a reduction in rainfall in many rangelands. The "current pace and scale of change is unprecedented" (SOS 2009), even though dryland communities, and pastoralists in particular, have always had to contend with change. The loss of perennial grass cover and increase in annuals, unpalatable species and bush cover are the major threats (Oba and Kotile 2001). In the view of Hobbs and Norton (1996), livestock grazing may have four noteworthy effects on critical ecological processes: defoliation of plants, soil trampling, fecal and urine mineral deposition. Heitschmidt et al. (2004) state the three major threats to ecological processes in rangelands as invasion of noxious species, the conversion of rangelands into other land uses and a critical decline in productivity due to soil degradation as a result of intensified erosion processes and overgrazing. In west Asian and north African rangeland, exceedance of the natural carrying capacity is responsible for the deterioration of these environments, combined with increasing cultivation of crops in steppe regions (Nefzaoui et al. 2002). Moreover, overgrazing has reduced the total productivity of African rangelands (Taha and Khidr 2011). Reduced productivity could lead to decreased efficiency in rangelands that can result in degraded lands or land-use transformation into urban or agricultural areas (Shoshany and Goldshleger 2002). The problem is accentuated in semi-arid lands and represents one of the most serious global environmental challenges and requires a solution (Hill et al. 1995; Kassahun et al. 2008).

\section{Field-based monitoring of rangeland degradation}

The assessment of degradation in arid rangelands is difficult due to short-term variations in rainfall, landscape diversity and the problems associated with sampling large areas (Pickup et al. 1998). Moreover, the pastoral systems have been characterized by high mobility, dynamism and a high dependency on local knowledge (SCBD 2010) to manage a highly diverse and complex environment, given the high spatial and temporal variability of the resources in the drylands (AU-IBAR 2012). Rangeland management as a discipline, observing alteration in forage, land cover and land use, is dependent upon the judgement and experience of field specialists and less on quantitative methods (Booth and Tueller 2003; West 2003). Existing strategies for rangeland evaluation can be divided into two main groups: traditional field techniques based on actual fieldwork, and direct measurements of surface cover, and remote-sensing methodologies based on non-intrusive measurements with limited fieldwork (Svoray et al. 2013). Monitoring rangeland using fieldwork techniques presents a challenge in arid and semi-arid areas due to the large geographical area, rough terrain and rich diversity over short distances. Data collection by fieldwork is time consuming and requires established field experience. Furthermore, fieldwork may also depend heavily upon the surveyors' judgement, whose work can become affected by attitude, bias, experience, integrity and stress (Booth and Tueller 2003), and is also subjective and costly (Louhaichi et al. 2010). Louhaichi et al. (2015) compared the traditional technician who measures plant cover (green leaf, litter, bare ground) against a vegetation index derived from classified field-based remote-sensing images. They found a high degree of variation between technicians in traditional monitoring, with results of estimated cover being highly subjective and commonly based on visual estimates (Coulloudon et al. 1999; Magill 1989). Furthermore, transects, quadrats and point methods which use sample positions vary and can be classed as selective, capricious, systematic and /or random (Larson et al. 2013). According to Olorunfemi (1983), undertaking systematic monitoring of changes and time series analysis is difficult with traditional methods of rangeland survey.

The estimation of vegetation cover for grasslands is imperative for livestock breeding, farming and desertification monitoring of arid and semi-arid lands. In these regions, information on biomass and the rangeland vegetation front is essential for livestock productivity. Taking decisions concerning the management of grazing animals on the basis of inadequate information can lead to the loss of animals, both as a consequence of forage shortage, and in overgrazing of 
vegetation; both factors can lead to rangeland degradation (Weber et al. 2000). In conditions of weather fluctuation, rangeland managers may seek to adjust stocking rates based on a thematic method able to estimate productivity on rangelands. Green vegetation cover is an important factor in regard to rangeland status and is a key sensitivity indicator of land degradation and desertification. Quantitative data on the green vegetation cover is necessary in numerous environmental change investigations worldwide and at local scale.

\section{Rangeland degradation in Libya}

Libyan rangelands have fragile ecosystems, as they are located within the arid and semi-arid region and half of the area, situated between the 50 and $200 \mathrm{~mm}$ isohyet zones, is under the $100-\mathrm{mm}$ isohyet. They have shallow soils formed over rocks, making them more sensitive to degradation from a lower degree of misuse; these rangelands face severe drought and deterioration in both vegetation cover and forage production. Dregne and Chou (1992) noted that the degradation of rangeland in Libya is more widespread compared to irrigated or rainfed areas. A combination of reasons have led to the poor conditions experienced in this rangeland. The most important of these factors include low rainfall and frequent droughts (El-Chaouch and Ben Mansoura, 1991; Alzznni et al. 1999), overgrazing, improper agricultural practices, mismanagement, seasonal fire outbreaks and wind, and water erosion (Omar Al Mukhtar University, 2005; Rangeland development project, 2008; El-Barasi and Saaed, 2013) cutting of woody species for use as a fuel (Nasr, 2004; El-Barasi et al. 2013). However, the human impact is the most profound factor accounting for the increased severity of rangeland change, through agricultural expansion at the expense of the rangelands, and mismanagement of rangelands and lack of fodder, overgrazing, combined with the cutting of woody species for use as a fuel, constituting the principal causes of the degradation (Omar Al-Mukhtar University 2005; Nasr 2004). One of the most important of these is the increase in stocking densities, where production has been exceeded by some threefold. The numbers of animals that can be accommodated in this area being circa 2.5 million, while the numbers have actually increased to approximately 7.5 million head (Rangeland Development Project 2008). With the increase in the number of pastoral animals and the unregulated use of pastures and grazing, vegetation cover reduction and degradation of the environment has occurred and consequent degradation of grazing for pastoralists in Libya. In addition, an increasing human population in some parts of the Libyan rangelands has led to the exploitation of these lands with irrigated crops to meet the needs of the population that has in turn led to decreasing areas of rangeland. For example, in the western rangeland, a large part of the area receiving $200 \mathrm{~mm}$ rainfall has been converted to cultivation of field crops (EL-Chaouch and Ben-Mansoura 1991). In addition, there has been a transfer of animals to low rainfall areas with consequent overgrazing, resulting in the extinction of many plants and exposure of the area to erosion and the emergence of surface rocks, especially in the high elevations and on slopes (BELCSS 2005). For example, the south-eastern rangeland of Al Jabal Alakhder suffers from overgrazing, due to the increase in the number of animals and their concentration in certain places, the decrease in the area of natural pastures and the seasonal migration of pastoralists. In 1987, the total number of animals (sheep, goats, cattle and camels) in this area was 89,079 head. By 2002, these numbers had increased to reach a total of c.202,386 head. In addition, grazing had become concentrated on specific water source locations (BELCSS 2005). The productivity of rangelands was degraded here both due to overgrazing and the elimination of the sources of seeds from pastoral plants. This led to a deficit in fodder units in the western region of the eastern rangeland, estimated to be about 285 feeder units per hectare per year for feeding a total of 908,199 head of sheep, camels and goats (BELCSS 2005). Grazing on trees and shrubs has also led to the decline of palatable species and the loss of condition of many other species. This has led to the elimination or reduced biomass quality of several types of perennial plants, which have high nutritional value. The fluctuation of rainfall from year to year can reduce vegetation quality and quantity, impacting on the amount of feed available to grazing animals. Continual drought years leads to a reduction in animal numbers due to lack of forage and the inability of livestock owners to provide supplemental feed due to its high cost. These types of perennial plants represent the rangeland's reserve in drought years and have been replaced by types of poor and less nutritious rangeland species (Omar $\mathrm{Al}$ Mukhtar University 2005). Alzznni et al. (1996) indicate that most of the main pastoral species such as Medicago laciniata (Nafal), Avena wiesth (Shufan bry) and Atriplex halimus (Alqatf almalhi) have disappeared in the southern $\mathrm{Al} \mathrm{Jabal} \mathrm{Al}$ Khader. They have been replaced by gaseous and poisonous plants such as Peganum harmala (Hrml), Haloxylon articulatum (Ramth), Anabasis articulata (Eajrum), Suaeda fruticosa (Alssuida) and Atractylis serratuloides (Alssir). Degradation in natural vegetation increases the expenditure required for pastoralists to provide supplemental feeding, reflected in the resultant rangeland condition. Annual livestock production has fluctuated due to poor rangeland and the inability of pastoralists to provide such supplements, with its relatively high cost. Figure 2 illustrates the principle factors that contribute to Libyan rangeland degradation.

\section{Role of remote sensing in monitoring rangeland degradation}

The application of remote-sensing techniques can play a significant role in rangeland monitoring. They provide opportunities to observe, monitor, predict and recognize 


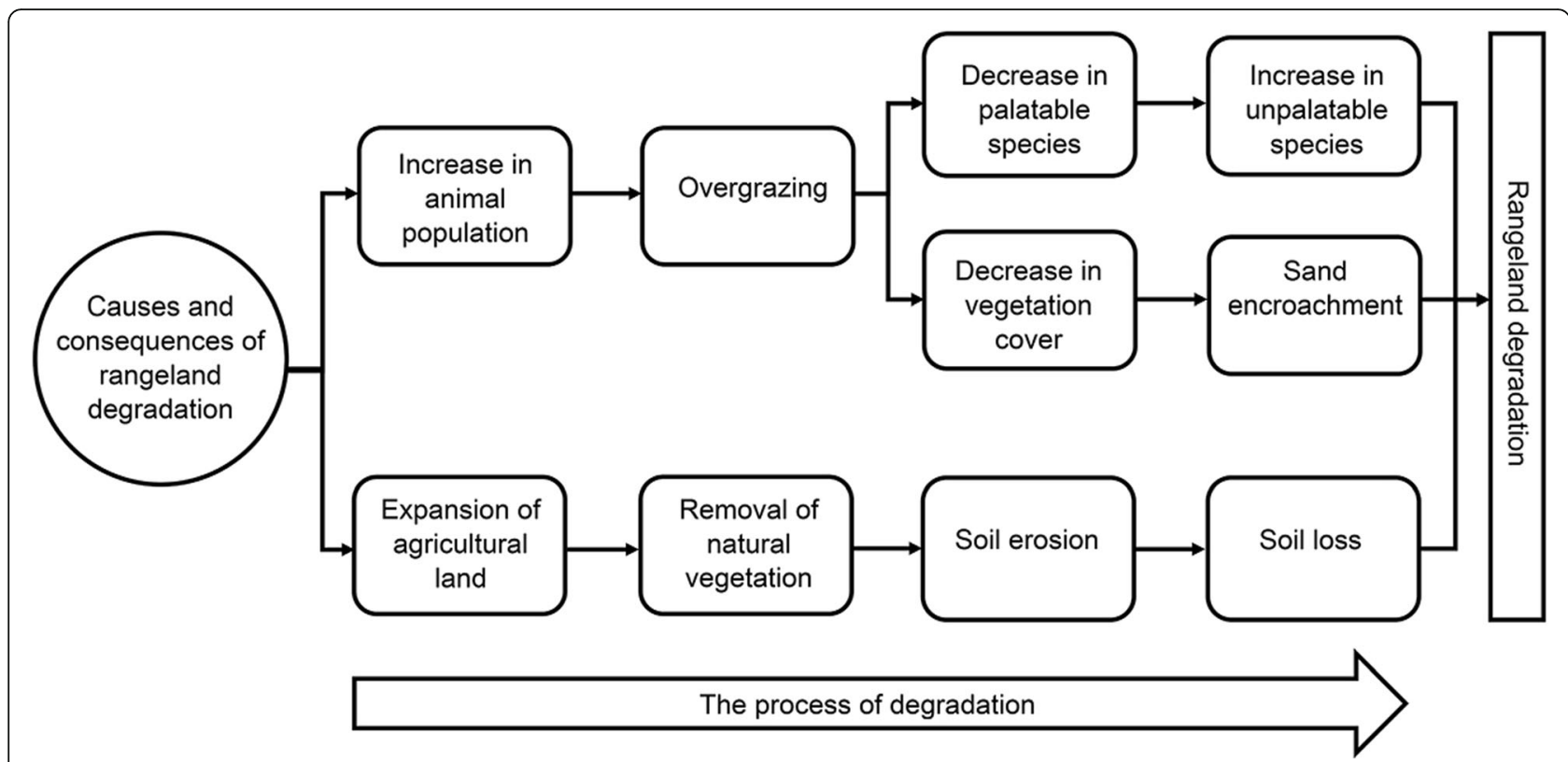

Figure 2 Causal factor chain in Libyan rangeland degradation

threats to ecological processes in rangelands. Remote sensing has been applied historically to provide three forms of data that are of use in rangeland monitoring: categorical and quantitative observation and dynamic monitoring. The data has the advantage of covering large areas with frequent repetitive image acquisition across multiple wavelengths. Application of a wide variety of methodologies to map surface components using these data can allow identification of invasive species, the detection of changes in vegetation and early warning of land degradation risks (Svoray et al. 2013).

\section{Remote-sensing data characteristics}

Remote-sensing data permit rangeland managers to analyse the spatial distribution of vegetation cover and types over time and to quantitatively analyse that vegetation. A fundamental property of remotely sensed data is its resolution. Aggarwal (2003) defined resolution as the capability of the system to provide information with the smallest discretely separable amount in terms of distance (spatial), wavelength band of electromagnetic radiation (spectral), time (temporal) and/or radiation quantity (radiometric). Remotely sensed data can be applied to estimate biophysical and phenological characteristics of vegetation at multiple spatio-temporal scales and extents (Coops et al. 2012; Jensen 1983; Kerr and Ostrovsky 2003; Washington-Allen et al. 2006). The spatial resolution of remotely sensed imagery varies from less than a metre to $1 \mathrm{~km}$ or more. Regional rangeland assessments typically use coarse spatial resolution imagery, for example, Moderate Resolution Imaging Spectroradiometer (MODIS) data, with a daytime visit cycle of one to two days, $\geq 250 \mathrm{~m}$ spatial resolution and 36 spectral bands. With more than a 15-year history, MODIS data has enabled a global land coverage, and one that is available as a free resource for both land managers and academic researchers (Reeves et al. 2015). In addition, the NOAA Advanced Very High-Resolution Radiometer (AVHRR) has provided global data since 1978. The capability of AVHRR information for monitoring rangeland has been demonstrated in many investigations (e.g. Tucker and Sellers 1986; Prince and Tucker 1986). The $1 \mathrm{~km}^{2}$ resolution of the AVHRR is ideal for continental-scale monitoring with a one-day global daytime repeat cycle providing data valuable for assessing regions that are sensitive to inter-yearly atmosphere changes (Svoray et al. 2013).

Data from the Landsat satellite series have been used to research alterations in land cover and land use (LCLU) of the whole globe at moderate spatial resolutions $(30 \mathrm{~m}$ and previously $80 \mathrm{~m}$ for the multispectral scanning system (MSS)) with a 16-day return interval since 1972 (Wulder et al. 2008). The image archive and new imagery are freely available. Serra et al. (2003) used Landsat MSS and Landsat TM implementing a protocol that permits reliable post-classification assessments to detect Spanish rangeland LCLU change over a 30-year period. Their results demonstrate that change detection using the protocol had an accuracy of $85.1 \%$, while using a direct overlay method was only $43.9 \%$ accurate. Vogelmann et al. (2012) conducted a study to evaluate progressive change using time series data derived from Landsat Thematic Mapper (TM) and Enhanced Thematic Mapper Plus (ETM+) within a US rangeland area over the period 1984 to 2010. The results indicated that Landsat time series data are 
appropriate for deriving rangeland landscape change information. Landsat images have also been used for monitoring and assessing rangeland degradation in Australia by relating vegetation cover and biomass with a field observed method (Graetz et al. 1983, 1986, 1988; Pech et al. 1986). Graetz (1987) noted that the practical use of remote sensing for rangeland management has been limited by the low accuracy of the extracted quantitative measurements, such as biomass and cover. However, this has changed since the availability of very high-resolution images, which offer spatial resolutions of less than a metre on the ground such as WorldView data. Everitt et al. (2008) applied QuickBird data to detect the invasion of giant reed (Arundo donax) within Rio Grande, southwest Texas, with an $86 \%$ overall accuracy. Also, the vegetation cover of sagebrush-steppe rangeland within northern Utah in 2010 was measured based upon an implementation of IKONOS data, able to identify 5\% more variation in shrub cover compared to using Landsat data alone (Sant et al. 2014).

By using the variation in the spectral response of different vegetation types, rangeland managers can identify indicators of rangeland quality and condition. Spectral resolution allows vegetation indices (VI), such as the Normalised Difference Vegetation Index (NDVI), to be derived that are appropriate to both low and high spatial resolution multispectral satellite sensors and all other systems that acquire data in the visible and near-infrared wavelengths. They can be used to evaluate green biomass and are likewise used as a proxy for natural changes, particularly with regard to drought and land degradation risk evaluation (Kogan 1990; Tripathy et al. 1996; Liu and Kogan 1996). Todd et al. (1998) used Landsat TM in 1991 to derive a number of vegetation indices utilizing the spectral resolution of the sensor. They found that the red waveband (RED) index was the most suitable index to estimate biomass variations of green vegetation found in grazed and ungrazed rangeland on the shortgrass steppe of eastern Colorado, and to a lesser extent when the vegetation was dry or senescent. Consequently, particular interest is centered on the evaluation of green biomass in arid environments where soil background forms a critical component of the signal detected.

\section{Vegetation mapping}

Monitoring vegetation cover is an essential process in rangeland management, as vegetation is the most effective indicator for identifying land degradation and it provides information that helps the understanding of climate and human impacts on rangeland condition. Quantification of ground cover as the proportion of ground covered by vegetation is amongst the most frequently used metric by rangeland managers in range management and ecosystem studies (Svoray et al. 2013). A wide range of available satellite sensor images have been used to map surface cover from different rangelands around the world including the Middle East, Europe, Africa, the Far East and Australia (Jensen et al. 2001; Williams and Hunt Jr 2002; Filippi and Jensen 2006; Fritz et al. 2008; Ustin et al. 2009; Masocha and Skidmore 2011). The accuracies of their classifications are typically $>70 \%$, demonstrating that remote sensing provides a usable tool for mapping and archiving surface measurements in rangelands. Landsat data has allowed the detection of land-cover conversions between consecutive dates that have a more permanent character and are independent of climate-induced fluctuations in surface attributes (Serra et al. 2003; Zhong and Wang 2006; Zhou et al. 2008; Berberoglu and Akin 2009; Svoray et al. 2013). The long data record of up to 40 years provides a period of assessment that can be meaningful from the ecological point of view. For example, Landsat MSS images have been used to detect rangeland changes from 1983 to 1992 in southern New Mexico, where extensive grasslands have gradually become a patchwork of shrub lands and relict grasslands (Yool et al. 1997). In another study from Arizona and Sonora, Mexico, Kepner et al. (2000) built up a straightforward method that consolidated remote-sensing data such as triplicate Landsat MSS imagery from the mid1970s, mid-1980s and 1990s to report changes. Wallace et al. (2003) used multi-temporal Landsat data from different sensors (Landsat 1,5 and 7) to measure LULC change and to relate spatial arrangement and composition to landscape structure and pattern.

With coarser spatial resolutions, such as MODIS, monitoring is likely to focus on vegetation cover and vegetation phenology as well as on a range of geomorphological and hydrological variables such as soil moisture. The study of change in these properties may significantly contribute to the understanding of rangeland dynamics in time and space. The reasons for this predominance are mainly the fine temporal resolution that these satellite sensors provide (daily data), but also the low (or zero) cost and the fact that remote sensing is used in many cases to study regional and even global phenomena (Svoray et al. 2013). Serneels et al. (2001) studied vegetation cover changes over more than a decade in Kenya's rangelands using NDVI derived from AVHRR and Landsat TM images. They found that by using both datasets, additional advantages are gained that cannot be obtained by using one of them alone, for example, sensitivity to inter-annual climate variations and determining land-cover conversions between consecutive dates. Gray and McCrary (1981) illustrated that the spatial representation of vegetation productivity indices obtained from AVHRR imagery could be associated 
with corresponding patterns of water deficit affecting plant growth. This association, coupled with the high temporal repeat interval of the TIROS-N satellites, led to the application of the NDVI, used to observe the impact of drought on rangeland over the African Sahel region (Tucker et al. 1983), and also by direct inference to predict the influence of drought on local community (Prince and Tucker 1986). As satellite imagery increases in resolution, so does the potential accuracy of the assessments. Utilizing very high spatial resolution sensors such as QuickBird for recognizing giant reed (Arundo donax), Everitt et al. (2008) enhanced accuracy by an average of $12 \%$ compared with using high-resolution SPOT 5 data alone.

Remote-sensing data have been used to study the biophysical properties of vegetation in open areas and, in many cases, in rangelands with the help of vegetation indices (Reeves et al. 2006; Hunt Jr and Miyake 2006; Fang et al. 2005). Amongst these vegetation indices, the most common is the NDVI. Extending this, the soil-adjusted vegetation index (SAVI) (Huete 1988) was promoted as a modification to the NDVI, allowing a corrected assessment of the impact of soil on the reflectance characteristics of green vegetation in semi-arid regions. SAVI has been applied extensively in regions of low vegetation cover (Reeves et al. 2015). Dymond et al. (1992) used multispectral SPOT imagery to gauge percentage vegetation cover in New Zealand to relate the ground estimation of percentage vegetation cover to a standardized vegetation index and built up a nonlinear calibration curve with 80\% confidence. Wittich and Hansing (1995) analysed the connection between NDVI and vegetation cover rate for zones with various types of land cover in western Germany utilizing NOAA AVHRR data. They applied statistical land cover information from the test region and demonstrated that NDVI was a reasonable indicator of the percentage vegetation cover.

Remote sensing provides the basis for accurate measurement of vegetation cover, being far quicker and more comprehensive as compared to fieldwork methods (Booth and Tueller 2003). As a consequence, remote sensing presents a viable source of data from which updated land-cover information can be extracted efficiently and cheaply in order to inventory and monitor changes in rangeland ecosystems effectively (Mas 1999). Booth and Tueller (2003) state that if rangeland managers seek unbiased and costeffective means of calculating vegetation cover, they should integrate remote-sensing techniques into rangeland assessments. Moreover, remote-sensing methods can be used to extract information that is directly related to a management question, or to create additional data layers that are correlated with concerns held by land managers.

\section{Evaluating rangeland productivity}

In regard to the assessment of rangeland productivity, remote-sensing products provide large areal cover, having higher temporal return frequencies, and greater spectral resolution compared to traditional rangeland field sampling. Measuring productivity is one of the most commonly used applications of remote sensing at global to regional scales in rangeland studies. Using remote sensing at global scales can provide insights into potential trajectories of change into the future (Reeves et al. 2015).

Vegetation productivity refers to the accumulated solar energy over time and area into biomass (Curran 1982). The measurement of reflectance in the visible and nearinfrared wavelengths gives remote-sensing data its ability to evaluate vegetative condition at various temporal resolutions. This capability allows the identification of rapidly changing vegetation productivity conditions at different spatial scales to be established for evaluating rangeland forage conditions and mostly includes the examination of statistical relationships amongst the variables estimated using remote sensing and ground observed data (Dungan 1998). In addition, in determining the strong correlation between field measurement of green biomass and remotely sensed derived vegetation indices, Rouse et al. (1973) demonstrated the potential for tracking vegetation growth over time, thus showing the capacity for the remote-sensing device to observe vegetation dynamics and thus the significance of the precise and continuous acquisition of remotely sensed data.

Vegetation indices can be applied to create predictive relations for calculating rangeland productivity. Bai et al. (2008) used trends in 8-km resolution NDVI from the Global Inventory Modeling and Mapping Studies (GIMMS) as a "proxy indicator" of changes in net primary productivity (NPP) from 1981 to 2003 resulting from the fusion of GIMMS NDVI and MODIS $1-\mathrm{km}^{2}$ NPP in the context of the Land Degradation Assessment in Drylands (LADA) programme. They estimated rain-use efficiency (RUE) from the ratio of the yearly sum of NDVI to annual rainfall and used it to identify and isolate areas where declining productivity was a function of drought.

At a regional scale, Tucker et al. (1983) applied both a direct and logarithmic regression between the groundmeasured biomass information in the Sahel area and AVHRR NDVI to predict biomass. Similarly, Yu et al. (2010) applied the 250-m resolution MODIS NDVI in the Tibetan Autonomous Prefecture of Golog, Qinghai, China, to predict aboveground green biomass utilizing regression relationships between remote-sensing-derived NDVI and ground-observed biomass from sites across the area with an $r^{2}$ correlation of 0.51 . Al-Bakri and Taylor (2003) also applied a linear regression method to 
estimate rangeland shrub biomass in Jordan utilizing AVHRR NDVI where a significant correlation $\left(r^{2}=0.75\right)$ with observed ground biomass was found. Prince et al. (2009) applied the approach of local net primary productivity scaling (LNS) in Zimbabwe at national scales, utilizing MODIS 250-m resolution NDVI, revealing that as a result of degradation, about $17.6 \mathrm{Tg} C$ were lost annually. Fava et al. (2012) implemented an annual summation of MODIS 250-m resolution NDVI in an LNS study for evaluating status of Mediterranean rangeland. This resulted in a mean agreement of $65 \%$ with degradation data from ground classification. In North-eastern South Africa, Wessels et al. (2007) employed 1-km timeintegrated NDVI in a similar approach.

However, using remote-sensing data with coarse spatial resolution has its limitations especially in areas with high fragmentation and heterogeneity of rangelands (Cohen and Shoshany 2002). Al-Bakri and Abu-Zanat (2007) assessed the relationships between vegetation indices and the total biomass of Jordan's rangeland with high temporal resolution data at the national level. They assessed the correlation between NDVI, derived from 10-m spatial resolution SPOT-5 HRV data, and vegetation biomass within a managed grazing area. Their findings demonstrated that vegetation biomass was strongly correlated $\left(r^{2}=0.77\right)$ with NDVI from SPOT-5 HRV.

NDVI has limitations with scattered low vegetation in rangeland, thus the emergence of other vegetation indices such as SAVI. In addition to SAVI, other vegetation indices have been applied to estimate biomass based on remote-sensing data, for example, the modified soiladjusted vegetation index (MSAVI) (Ren et al. 2011; Boschetti et al. 2007) and the Enhanced Vegetation Index (EVI) (Casady et al. 2013; Boschetti et al. 2007). Vegetation indices such as the Modified Simple Ratio (Chen and Cihlar 1996) and the Renormalized Difference Vegetation Index (Roujean and Breon 1995; Gao et al. 2013) are considered more linearly related to various characteristics of aboveground biomass whereas EVI, SAVI and MSAVI are better correlated with ground data of biomass that addresses soil incorporation in the spectral response (Jin et al. 2014). In Mongolian rangelands, Kawamura et al. (2005) illustrate that $80 \%$ of the variation in live biomass and $77 \%$ of the change in total biomass, and live and dead biomass and crude protein in standing biomass, was explained by the application of a $500 \mathrm{~m}$ resolution MODIS EVI with linear regression models.

\section{Mapping invasive species}

The effect of invasive and especially noxious species on rangelands is substantial. Masocha and Skidmore (2011) utilized remotely sensed data, integrated into a geographical information system (GIS)-based expert system, a neural network (NN) and support vector machine
(SVM), to test their contribution to invasive species cover maps to map four cover classes of the invasive shrub Lantana camara in Zimbabwe. The mapping of $L$. camara and application of the NN and SVM resulted in kappa accuracies of 0.77 and 0.67 , respectively. Juniper infringement into shrub steppe and grassland systems stands out amongst the most noticeable changes underway in the rangelands of western North America. Sankey et al. (2010) fused Landsat 5 TM imagery and light detection and ranging (lidar)-based classifications to evaluate juniper expansion patterns in Idaho achieving $83 \%$ overall accuracy. Other studies have used QuickBird images (Starks et al. 2011) and colour aerial photographs (Naylor et al. 2005) to map invasive species in rangelands. Using high spatial resolution sensors has allowed increases in species differentiation (Everitt et al. 2008; Mansour et al. 2012) and vegetation cover characteristics (Sant et al. 2014). Furthermore, unmanned aerial vehicles can be used to provide such imagery at fine spatial resolutions for rangeland monitoring purposes and, in particular, the identification of plants to species level (Laliberte et al. 2010). The use of hyperspectral data has permitted the mapping of intrusive species based on several distinctive bio-physical attributes associated with multispectral sensors. Parker Williams and Hunt Jr (2004) applied the Airborne Visible/Infrared Image Spectrometer (AVIRIS) data to identify leafy spurge with an accuracy of $95 \%$ overall; similarly, Oldeland et al. (2010) exposed bush encroachment by Acacia spp.

\section{Monitoring vegetation and soil moisture}

As many of the rangelands on Earth are situated in dry areas, soil moisture is amongst the most important variables to be monitored using remote-sensing technologies. An important measure of rangeland functioning is moisture level in the vegetation canopy, an expression of its physiological status. The complementary measure is the soil moisture content. Long periods of dry soil and low levels of canopy moisture, as well as more readily detectable decreases in leaf area index (LAI), can imply a deteriorating ecosystem due to drought impact. Decreases in LAI and canopy moisture can, therefore, provide important information on the health of plants and on drying processes due to drought years or climatic change. Since plants are expected to dry out slowly before mortality (Claudio et al. 2006), it is useful to monitor LAI and water content in the canopy. The remotesensing data (hyperspectral and multispectral data) have been used in several studies for accurate estimation of canopy water content of grasses and grazed fen meadow (Clevers et al. 2010). Canopy moisture assessment includes attempts to estimate daily evapotranspiration (ET) fluxes at the catchment scale from NOAA AVHRR data (Kustas et al. 1994). The addition of two spectral 
bands calibrated to the short-wave infrared portion of the electromagnetic (EM) spectrum on Landsat Thematic Mapper (TM) provided the ability to monitor leaf moisture (Tucker 1980; Hunt Jr and Rock 1989) as well as identify and map recent wildfires (Chuvieco and Congalton 1988; Key and Benson 1999).

\section{Monitoring and mapping fire extent}

Monitoring and mapping of rangeland fire extent using remote-sensing data provides an insightful baseline for evaluation of potential future development of fire incident risk and its impact on ecosystem functioning. Loboda et al. (2012) noted that MODIS-based products deliver spatially accurate assessments of burned areas in Central Asia; this is similar to results obtained within North American drylands (Giglio et al. 2009). MODISbased products can be utilized to produce consistent evaluation of fire influences on rangeland. The foremost, widely applied index for mapping and evaluating burn severity relies on the normalized difference of NIR and SWIR, initially proposed by López-García and Caselles (1991) for mapping burned regions.

\section{Implications for Libyan rangeland management}

Range management is characterized as "the manipulation of rangeland components to obtain the optimum combination of goods and services for society on a sustained basis" (Holechek et al. 2011), which further note that sustainable rangeland management must consider integration of environmental, economic and social values. Investment in the agricultural sector by the Libyan government during the 1970 s and early 1980 s led to many rangeland development projects, designed to achieve both development of rangeland resources as well as self-sufficiency in red meat production. However, this caused a rapid expansion of livestock numbers and land cultivation of these resources (Jansen 1988). These development projects lacked any effective means of collecting regular information on project outcomes. Fluctuations in rangeland resource policies such as changing grazing rights from tribal to the state level without stabilizing control of either stocking rate or the period and season of use further prevented achievement of sustainable utilization of these resources.

Management practices, applied in recent years in Libyan rangelands, have been dependent on established patterns of rainfall. Areas receiving relatively high amounts of rainfall can be protected and managed by intensive development work such as fencing for several years, with reseeding and cultivation of palatable pastoral plants, and ploughing of the land to increase infiltration of the water in the plant root zone. Lands receiving lower rainfall rates are not taken into intensive development operations, but can be developed and invested in an orderly fashion through the distribution of water points (wells) and the provision of accompanying services (care and mowing) and regulation of grazing (Rangeland Development Project 2008). These practices can help reverse degradation within Libyan rangeland. Moreover, Swedish Consultants (SWECO) (1986) and Alzznni (2002) recommend that the area of natural rangeland is divided into sections of $400 \mathrm{~km}^{2}$ in a rectangular form extending from north to south. These areas include diverse environmental systems and gradients in terms of rainfall and vegetation cover.

Although there are a wide range of fieldwork techniques used for monitoring rangeland degradation, the costs of such methods are significantly higher than remote-sensing methods in comparison with the accuracy and reliability achievable, both in time and resources required. In addition, administration approaches in rangelands seek to keep the cost of monitoring low, and high fieldwork costs do not encourage sufficient samples to be taken to cover the whole of the area monitored. There is an inherent difficulty in all rangeland studies in collecting data, given the large geographical areas involved. This is especially true in Libya, where there is a particularly high cost of inventory. Moreover, there is a lack of the regularly updated information needed for monitoring in this area. In addition, the periods of time between the studies are not integrated with each other and are not repeatable, making it difficult for rangeland managers to detect rangeland degradation in a consistent manner. This is because most studies, which measure rangeland condition, are heavily reliant on fieldwork techniques (EL-Chaouch and Ben-Mansoura 1991; Alzznni et al. 1999; Omar Al-Mukhtar University 2005; El-Barasi and Saaed 2013; El-Barasi et al. 2013; Aburas 2014).

This has led to a lack of time-series data that precludes the development of informed management prescriptions to support the improvement of rangeland in this region (Nasr 2004). There have been recommendations since 1992 for decision-makers in North Africa to establish long-term monitoring systems for collecting and evaluating rangeland resource information (Sidahmed 1992). Because rangeland management systems need effective monitoring systems, this should further help to serve as an early warning system for rangeland degradation (Reed and Dougill 2010). Such information can help to detect potential problems and can provide data to enable better decisions to be made for the future, to ensure sustainable land use (Khiralla 2013). The emphasis on change is what makes monitoring different from simple inventories of rangeland (De Gruijter et al. 2006). To perform these duties, Libyan rangeland managers must apply remote-sensing data to extract information on 
rangeland condition that can be used in guiding and supporting rangeland management.

Fairly recently, researchers in Libya incorporated remote-sensing data to assess Libyan natural resources as either primary data or secondary data tackling many of the problems associated with salinity and erosion, and mapping land use in general (FAO 2011). Remote-sensing data has been used to map natural resources for agricultural use and planning in Libya. However, little consideration has been taken of the rangeland resource even though it covers nearly two thirds of the country. Some studies have been conducted in Libyan rangeland that include remote-sensing data resources. Mnsur and Rotherham (2010) used Landsat TM and Landsat ETM+ data to detect the change of land cover/land use with time series in selected areas of Al Jabal Alakhder (Maroa, Gandolla and Omar Al Mukhtar) from 1984 to 2005 applying a supervised classification method. Their results show that the vegetation has experienced several problems that have led to loss of cover. However, Elaalem et al. (2013) applied supervised classification using SPOT 5 imagery for evaluating land cover/land use in the north-west region of the Jeffara Plain. They found this approach led to the production of inaccurate land cover classes due to the limitations of the supervised classification adopted when classifying heterogeneous land cover/use classes.

Remote-sensing techniques could play a significant role in addressing the issue of monitoring Libyan rangeland, implementing techniques that have been successfully applied in similar rangelands globally. The techniques employed in Libya are considered as being inadequate to meet these expected needs for up-to-date Libyan rangeland information at national scales of survey and monitoring (Ben-Mahmoud 2001). Remote sensing can help to reveal the causes of degradation of the rangeland ecosystem, and provide managers with sufficient data to assist their rangelands.

Future rangeland management in Libya must consider issues related to stock breeding and production to meet planned targets, with self-sufficiency in red meat production. When this is undertaken without taking into account the sustainable use of the ecosystem, there is a consequent deterioration of rangeland (vegetation and soil). The majority of Libyan rangeland under the $100-\mathrm{mm}$ isohyet is too degraded in terms of both soil fertility and vegetation for recovery within the short term either by natural improvement or even with human assistance. Cultivation practices within rangeland, where the rangeland has been converted to cultivation of field crops (El-Chaouch and Ben Mansoura, 1991; Jansen, 1988; El-Barasi and Saaed, 2013; EL-Barasi et al. 2013; Aburas, 2014) has increased, resulting in damage to the natural vegetation through the widespread availability of tractors and disk ploughs for increasing grain production.
Such practices have exerted serious impacts on the soil resources during ground preparation, making the rangeland more vulnerable to subsequent soil erosion.

Monitoring of rangeland using ground-based measurement techniques presents a challenge in arid and semi-arid regions due to their variation in vegetation, soil, rainfall and terrain patterns over short distances (Figure 1). The administration of Libyan rangeland requires the institution of effective monitoring systems, able to assess the wide extent of rangeland. To date, this task has been performed through fieldwork methods, a costly process in terms of human and financial resources. Reliance on field methods limits the ability of Libyan rangeland managers to meet the requirement of effective monitoring systems that aid the detection of potential problems, providing data to enable better future decisions to be made, regulations alone not being adequate to ensure sustainable rangeland.

Remote-sensing methods constitute a powerful tool and offer the most important information source for assessing land surface processes since they provide dynamic, multi-temporal and time series information (Wu 2009) and also provide a viable source of data from which updated land-cover information can be extracted efficiently and cheaply in order to monitor changes effectively (Khiralla 2013; Louhaichi et al. 2010). As a consequence of its advantages, the use of remotesensing data can play a significant role in addressing the challenges facing the short- and long-term monitoring of Libyan rangeland. Moreover, applying remotely sensed monitoring methodologies in rangelands helps to overcome the limitation whereby site-based monitoring can only feasibly cover a small total area (Ludwig and Bastin 2008). Understanding rangeland response in both ongoing management and in addressing new pressures is fundamental in evaluating its long-term history (Blench 2000). In addition, it can be used for evaluating and assessing past measures applied in Libya to inform the formulation of future programs (Ben-Mahmoud 2001) by using available archives of remote-sensing data. The combination of remotely sensed data, together with other data such as climate, soil and management, would serve to create long-term monitoring systems to understand the rangeland conditions and their response to management. Moreover, remote-sensing methods can be used to extract information related directly to management questions, or to create additional data layers that are correlated to the ecological properties that managers are ultimately interested in. The most appropriate techniques for Libyan rangeland managers involve the derivation of vegetation indices for monitoring and assessing change detection of vegetation cover and biomass, and the application of regression approaches to establish the relationship between field ground observation data and 
these indices. The selection of appropriate indices need to be matched with Libyan rangeland conditions where vegetation cover is low, mixed with varied soil backgrounds.

\section{Conclusions}

Rangeland in Libya plays a significant role from both economic and environmental perspectives. However, its capacity to deliver these services has become undermined as vegetation cover has changed both qualitatively and quantitatively over the past four decades as a consequence of natural and human factors. The human factors have exerted a significant contribution to the deterioration of rangelands through mismanagement, with an associated lack of effective means of regularly collecting information on rangeland to help managers to detect potential problems related to their rangeland planning, mitigating the risk of rangeland degradation.

Remote sensing gives rangeland managers the ability to monitor rangeland using dependable and repeatable methods, utilizing timely data for vegetation spatial and temporal coverage (Purevdorj et al. 1998). Where these data are derived from satellite-borne sensors, wide area coverage is available on a regular basis and contemporary data can often be complemented with access to an archive allowing a historical perspective of landscape change to be obtained (Friedel et al. 2000).

The significance of changes in Libyan rangeland vegetation cover can be assessed and evaluated using remote-sensing data by applying successful approaches that have been utilized globally, and long-term monitoring systems established to understand the response of historical and current rangeland management. This approach will provide data indicators to allow better decisions to be made for the future, to ensure sustainable use of rangeland in providing services for pastoral communities.

\section{Acknowledgements}

The authors acknowledge the Libyan Ministry of Higher Education and Scientific Research, for supporting this work. This research was supported by affiliation to the UK Natural Environment Research Council (NERC) (NE/ M009009/1). We acknowledge the use of the "Ecosystem Services Databank and Visualisation for Terrestrial Informatics" facility, supported by NERC (NE/L012774/1).

\section{Funding}

The research was supported by the Libyan Government through the scholarship programme of the Ministry of Higher Education and Scientific Research.

\section{Availability of data and materials}

Not applicable.

\section{Authors' contributions}

AA conducted the work and wrote the manuscript with support from $\mathrm{SH}$ and TB. All authors read and approved the final manuscript.

\section{Competing interests}

The authors declare that they have no competing interests.

\section{Publisher's Note}

Springer Nature remains neutral with regard to jurisdictional claims in published maps and institutional affiliations.

\section{Author details}

'School of Water, Energy and Environment, Cranfield University, Bedford MK43 OAL, UK. ${ }^{2}$ Faculty of Natural Resources and Environmental Sciences,

Omar Al-Mukhtar University, Al-bayda, Libya.

Received: 22 October 2017 Accepted: 11 March 2018

Published online: 24 April 2018

\section{References}

Aburas, M. M. 2014. Soil erosion, crusting and degradation in the South of Al Jabal al Akhdar, Libya. International Conference of Agricultural Engineering, Zurich, Switzerland, 06-10 July 2014.

Aggarwal, S. 2003. Earth resource satellites. Satellite remote sensing and GIS applications in agricultural meteorology, Dehra Dun, India, 7-11 July, 2003.

Ahmad, S.S., and H. Ehsan. 2012. Analyzing the herbaceous flora of Lohi Bher Wildlife Park under variable environmental stress. Pakistan Journal of Botany 44 (1): 11-14.

Al-Bakri, J., and J. Taylor. 2003. Application of NOAA AVHRR for monitoring vegetation conditions and biomass in Jordan. Journal of Arid Environments 54 (3): 579-593.

Al-Bakri, J.T., and M.M. Abu-Zanat. 2007. Correlating vegetation cover and biomass of a managed range reserve with NDVI of SPOT-5 HRV. Jordan Journal of Agricultural Sciences 3: 26-40.

Alzznni, S. 2002. A study on the legislative reform and development programs to protect rangeland, forests and sustainable development in Libya and the Arab world. In Expert meeting on the development and coordination of regulations for the protection of rangeland and forests in the Arab world 2-4/ 2002. Lattakia: (in Arabic).

Alzznni, S.A., O.R. Saadi, and M.A. Bayoumi. 1996. The effect of degradation of natural vegetation in the Green Mountain region on biodiversity. In International Day of Biodiversity, 29 December 1996. Al Bayda: Omer Al Mukhtar University. (in Arabic).

Alzznni, S.A., O.R. Saadi, and M.A. Bayoumi. 1999. The impact of environmental factors on natural rangeland. Journal of Arts and Sciences, Garyounis University, Faculty of Arts and Sciences, Almrj (3): 160-143 (in Arabic).

AU-IBAR. 2012. Rational use of rangelands and fodder crop development in Africa. In AU-IBAR monographic series no. 1. Nairobi: African Union Interafrican Bureau for Animal Resources (AU-IBAR).

Bai, Z.G., D.L. Dent, L. Olsson, and M.E. Schaepman. 2008. Proxy global assessment of land degradation. Soil Use and Management 24 (3): 223-234.

BELCSS (Bureau of Engineering Land for Consultancy, Studies and Survey Works). 2005. A study for the identification of extinct plants and the development of a plan for pastoral grazing after matching with the status of rangeland. Technical report. Almarj. (in Arabic).

Ben-Mahmoud, K. 2001. Soil resources in Libya, national report. In Workshop on SOTER database on 12-16 November 2011, SOTER database FAO SubRegional Office for the North Africa, Rabat.

Berberoglu, S., and A. Akin. 2009. Assessing different remote sensing techniques to detect land use/cover changes in the eastern Mediterranean. International Journal of Applied Earth Observation and Geoinformation 11 (1): 46-53.

Blench, R. 2000. Extensive pastoral livestock systems: Issues and options for the future. Roma: FAO.

Booth, D.T., and P.T. Tueller. 2003. Rangeland monitoring using remote sensing. Arid Land Research and Management 17 (4): 455-467.

Boschetti, M., S. Bocchi, and P.A. Brivio. 2007. Assessment of pasture production in the Italian Alps using spectrometric and remote sensing information. Agriculture, Ecosystems \& Environment 118 (1-4): 267-272.

Bounejmate, M., B.E. Norton, A. Khatib, N. Bathikh a, F. Ghassali, M. El Mourid, and H. Mahyou. 2004. Partnership for understanding land use-cover change and reviving overgrazed rangeland in Mediterranean areas: ICARDA's experience. In Réhabilitation des pâturages et des parcours en milieux méditerranéens, ed. Ferchichi A. (comp.) and Ferchichi A. (collab.), 267-283. Zaragoza: CIHEAM (Cahiers Options Méditerranéennes; n. 62).

Casady, G.M., W.J. Van Leeuwen, and B.C. Reed. 2013. Estimating winter annual biomass in the Sonoran and Mojave Deserts with satellite- and groundbased observations. Remote Sensing 5 (2): 909-926. 
Chen, J.M., and J. Cihlar. 1996. Retrieving leaf area index of boreal conifer forests using Landsat TM images. Remote Sensing of Environment 55 (2): 153-162.

Chuvieco, E., and R.G. Congalton. 1988. Mapping and inventory of forest fires from digital processing of TM data. Geocarto International 3 (4): 41-53.

Claudio, H.C., Y. Cheng, D.A. Fuentes, J.A. Gamon, H. Luo, W. Oechel, H.-L. Qiu, A.F. Rahman, and D.A. Sims. 2006. Monitoring drought effects on vegetation water content and fluxes in chaparral with the $970 \mathrm{~nm}$ water band index. Remote Sensing of Environment 103 (3): 304-311.

Clevers, J.G., L. Kooistra, and M.E. Schaepman. 2010. Estimating canopy water content using hyperspectral remote sensing data. International Journal of Applied Earth Observation and Geoinformation 12 (2): 119-125.

Cohen, Y., and M. Shoshany. 2002. A national knowledge-based crop recognition in Mediterranean environment. International Journal of Applied Earth Observation and Geoinformation 4 (1): 75-87.

Coops, N.C., T. Hilker, C.W. Bater, M.A. Wulder, S.E. Nielsen, G. McDermid, and G. Stenhouse. 2012. Linking ground-based to satellite-derived phenological metrics in support of habitat assessment. Remote Sensing Letters 3 (3): 191-200.

Coulloudon, B., K. Eshelman, J. Gianola, N. Habich, L. Hughes, C. Johnson, and J. Willoughby. 1999. Sampling vegetation attributes, technical reference 1734-4. Denver, Colorado: Bureau of Land Management.

Curran, P.J. 1982. Multispectral photographic remote sensing of green vegetation biomass and productivity. Photogrammetric Engineering and Remote Sensing 48 (2): 243-250.

Darag, A. and Yousif, E. 1996. The savannah rangeland of the Sudan. Dryland Husbandry in the Sudan. Workshop report. OSSREA, DHP publications series, edited by tegegne Teka.

De Gruijter, J., D.J. Brus, M.F. Bierkens, and M. Knotters. 2006. Sampling for natural resource monitoring. Berlin, Heidelberg: Springer Science \& Business Media

Development Commission of Rangeland Project. 1980. Report development Commission of Rangeland, the general secretariat of the agricultural land reclamation and reconstruction, Libya (in Arabic).

Dregne, H.E., and N.T. Chou. 1992. Global desertification dimensions and costs. In Degradation and restoration of arid lands, ed. H.E. Dregne, 249-282. Lubbock, TX: Texas Tech Univ Press.

Dungan, J. 1998. Spatial prediction of vegetation quantities using ground and image data. International Journal of Remote Sensing 19 (2): 267-285.

Dutilly-Diane, C. 2007. Pastoral economics and marketing in North Africa: A literature review. Nomadic Peoples 11 (1): 69-90

Dymond, J., P. Stephens, P. Newsome, and R. Wilde. 1992. Percentage vegetation cover of a degrading rangeland from SPOT. International Journal of Remote Sensing 13 (11): 1999-2007.

Elaalem, M.M., Y.D. Ezlit, A. Elfghi, and F. Abushnaf. 2013. Performance of supervised classification for mapping land cover and land use in Jeffara Plain of Libya. International Proceedings of Chemical, Biological \& Environmental Engineering 55. 33-37.

EL-Barasi, Y. M., Barrani, M. W. and Al Tajoury, R. O. 2013. Land deterioration of a semi-desert grazing area in the north-eastern zone of Libya (Cyrenaica). Journal of Environmental Science and Engineering. B 2 (6B):357.

El-Barasi, Y. M. M. and Saaed, M. W. B. 2013. Threats to plant diversity in the north eastern part of Libya (El-Jabal El-Akahdar and Marmarica Plateau). Journal of Environmental Science and Engineering. A 2 (1A):41.

EL-Chaouch, O. M. and Ben-Mansoura, A. 1991. Assessment of the current status of Libyan pastures, the Technical Centre for Environmental Protection.

Everitt, J., C. Yang, R. Fletcher, and C. Deloach. 2008. Comparison of QuickBird and SPOT 5 satellite imagery for mapping giant reed. Journal of Aquatic Plant Management 46: 77.

Fang, H.L., S. Liang, M.P. McClaran, W.J.D. Van Leeuwen, S. Drake, S.E. Marsh, A.M. Thomson, R.C. Izaurralde, and N.J. Rosenberg. 2005. Biophysical characterization and management effects on semiarid rangeland observed from Landsat ETM+ data. IEEE Transactions on Geoscience and Remote Sensing 43: 125-134.

FAO. 2011. FAO. Achievements in Libya. FAO, Roma. http://www.fao.org/3/aba0018e.pdf. Accessed 7 Apr 2018

Fava, F.P., R. Colombo, S. Bocchi, and C. Zucca. 2012. Assessment of Mediterranean pasture condition using MODIS normalized difference vegetation index time series. Journal of Applied Remote Sensing 6: 12.

Favretto, N., L. Stringer, A. Dougill, M. Dallimer, J. Perkins, M. Reed, J. Atlhopheng, and K. Mulale. 2016. Multi-criteria decision analysis to identify dryland ecosystem service trade-offs under different rangeland land uses. Ecosystem Services 17: 142-151.

Filippi, A.M., and J.R. Jensen. 2006. Fuzzy learning vector quantization for hyperspectral coastal vegetation classification. Remote Sensing of Environment 100 (4): 512-530.
Friedel, M., W. Laycock, and G. Bastin. 2000. Assessing rangeland condition and trend. Field and laboratory methods for grassland and animal production research, 227-262. Wallingford: CABI Publishing.

Fritz, S., M. Massart, I. Savin, J. Gallego, and F. Rembold. 2008. The use of MODIS data to derive acreage estimations for larger fields: A case study in the south-western Rostov region of Russia. International Journal of Applied Earth Observation and Geoinformation 10 (4): 453-466.

Gao, Y., X. Liu, C. Min, H. He, G. Yu, M. Liu, X. Zhu, and Q. Wang. 2013. Estimation of the north-south transect of Eastern China forest biomass using remote sensing and forest inventory data. International Journal of Remote Sensing 34 (15): 5598-5610.

Giglio, L., T. Loboda, D.P. Roy, B. Quayle, and C.O. Justice. 2009. An active-fire based burned area mapping algorithm for the MODIS sensor. Remote Sensing of Environment 113 (2): 408-420.

Graetz, R. 1987. Satellite remote sensing of Australian rangelands. Remote Sensing of Environment 23 (2): 313-331.

Graetz, R., M. Gentle, R.P. Pech, J. O'Callaghan, and G. Drewien. 1983. The application of Landsat image data to rangeland assessment and monitoring: An example from South Australia. The Rangeland Journal 5 (2): 63-73.

Graetz, R., R. Pech, M. Gentle, and F. O'callaghan. 1986. The application of Landsat image data to rangeland assessment and monitoring: The development and demonstration of a land image-based resource information system (LIBRIS). Journal of Arid Environments 10 (1): 53-80.

Graetz, R., R.P. Pech, and A. Davis. 1988. The assessment and monitoring of sparsely vegetated rangelands using calibrated Landsat data. International Journal of Remote Sensing 9 (7): 1201-1222.

Gray, T. I. and McCrary, D. G. 1981. The environmental vegetation index, a tool potentially useful for arid land management. AGRISTARS Report EW-N1_04076, JSC-17132, Columbia, MO. https://ntrs.nasa.gov/search.jsp?R=19810020967. Accessed 8 Apr 2018.

Heitschmidt, R., L. Vermeire, and E. Grings. 2004. Is rangeland agriculture sustainable? Journal of Animal Science 82 (13_suppl): E138-E146.

Hill, J., J. Megier, and W. Mehl. 1995. Land degradation, soil erosion and desertification monitoring in Mediterranean ecosystems. Remote Sensing Reviews 12 (1-2): 107-130.

Hobbs, R.J., and D.A. Norton. 1996. Towards a conceptual framework for restoration ecology. Restoration Ecology 4 (2): 93-110.

Holechek, J.L., R.D. Pieper, and C.H. Herbel. 2011. Range Management: Principles and Practices. 6th ed., Upper Saddle River: Pearson.

Huete, A.R. 1988. A soil-adjusted vegetation index (SAVI). Remote Sensing of Environment 25 (3): 295-309.

Hunt, E.R., Jr., and B.A. Miyake. 2006. Comparison of stocking rates from remote sensing and geospatial data. Rangeland Ecology \& Management 59 (1): 11-18.

Hunt Jr, E.R., and B.N. Rock. 1989. Detection of changes in leaf water content using near-and middle-infrared reflectances. Remote Sensing of Environment 30 (1): 43-54.

Jansen, H. C. 1988. Range development in northern Libya. Rangelands 10(4): 178-182.

Jensen, J.R. 1983. Biophysical remote sensing. Annals of the Association of American Geographers 73 (1): 111-132.

Jensen, M.E., J.P. Dibenedetto, J.A. Barber, C. Montagne, and P.S. Bourgeron. 2001. Spatial modeling of rangeland potential vegetation environments. Journal of Range Management: 528-536.

Jin, Y., X. Yang, J. Qiu, J. Li, T. Gao, Q. Wu, F. Zhao, H. Ma, H. Yu, and B. Xu. 2014. Remote sensing-based biomass estimation and its spatio-temporal variations in temperate grassland, Northern China. Remote Sensing 6 (2): 1496-1513.

Kassahun, A., H. Snyman, and G. Smit. 2008. Impact of rangeland degradation on the pastoral production systems, livelihoods and perceptions of the Somali pastoralists in Eastern Ethiopia. Journal of Arid Environments 72 (7): 1265-1281.

Kauffman, J.B., R.L. Beschta, N. Otting, and D. Lytjen. 1997. An ecological perspective of riparian and stream restoration in the western United States. Fisheries 22 (5): 12-24.

Kawamura, K., T. Akiyama, H. Yokota, M. Tsutsumi, T. Yasuda, O. Watanabe, G. Wang, and S. Wang. 2005. Monitoring of forage conditions with MODIS imagery in the Xilingol steppe, Inner Mongolia. International Journal of Remote Sensing 26 (7): 1423-1436.

Kepner, W.G., C.J. Watts, C.M. Edmonds, J.K. Maingi, S.E. Marsh, and G. Luna. 2000. A landscape approach for detecting and evaluating change in a semi-arid environment. Environmental Monitoring and Assessment 64(1):179-195.

Kerr, J.T., and M. Ostrovsky. 2003. From space to species: Ecological applications for remote sensing. Trends in Ecology \& Evolution 18 (6): 299-305.

Key, C., and N. Benson. 1999. Measuring and remote sensing of burn severity. In Proceedings joint fire science conference and workshop. 
Khiralla, N.I.A. 2013. Monitoring and assessment of rangeland in semi arid areas of Sudan using remote sensing techniques North Kordofan State. Sudan University of Science and Technology.

Kogan, F. 1990. Remote sensing of weather impacts on vegetation in nonhomogeneous areas. International Journal of Remote Sensing 11 (8): 1405-1419.

Kustas, W., E. Perry, P. Doraiswamy, and M. Moran. 1994. Using satellite remote sensing to extrapolate evapotranspiration estimates in time and space over a semiarid rangeland basin. Remote Sensing of Environment 49 (3): 275-286.

Laliberte, A.S., J.E. Herrick, A. Rango, and C. Winters. 2010. Acquisition, orthorectification, and object-based classification of unmanned aerial vehicle (UAV) imagery for rangeland monitoring. Photogrammetric Engineering \& Remote Sensing 76 (6): 661-672.

Larson, L.L., M. Louhaichi, P.E. Clark, and D.E. Johnson. 2013. An efficient sampling protocol for sagebrush/grassland monitoring. In Proceedings of the 22nd International Grasslands Congress, ed. Michalk, D.L., Millar, G.D., Badgery, W.B., Broadfoot, K.M. Held in Sydney, Australia, 15-19 September 2013. Orange New South Wales, Australia: New South Wales Department of Primary Industry: 877-878.

Li, X.L., J. Gao, G. Brierley, Y.M. Qiao, J. Zhang, and Y.W. Yang. 2013. Rangeland degradation on the Qinghai-Tibet plateau: Implications for rehabilitation. Land Degradation \& Development 24 (1): 72-80

Liu, W., and F. Kogan. 1996. Monitoring regional drought using the vegetation condition index. International Journal of Remote Sensing 17 (14): 2761-2782.

Loboda, T.V., L. Giglio, L. Boschetti, and C.O. Justice. 2012. Regional fire monitoring and characterization using global NASA MODIS fire products in dry lands of Central Asia. Frontiers of Earth Science 6 (2): 196-205.

López-García, M.J., and V. Caselles. 1991. Mapping burns and natural reforestation using Thematic Mapper data. Geocarto International 6 (1): 31-37. https://doi.org/10.1080/10106049109354290.

Louhaichi, M., Clifton, K. and Johnson, D. E. 2015. A digital geo-referencing system for monitoring ground cover in drylands. Combating drought, land degradation and desertification for poverty reduction and sustainable development the contribution of science, technology, traditional knowledge and practices 9-12 March 2015, Cancún, Mexico.

Louhaichi, M., M.D. Johnson, A.L. Woerz, A.W. Jasra, and D.E. Johnson. 2010. Digital charting technique for monitoring rangeland vegetation cover at local scale. International Journal of Agriculture and Biology 12 (3): 406-410.

Ludwig, J.A., and G.N. Bastin. 2008. Rangeland condition: Its meaning and use. In A discussion paper prepared for the Australian Collaborative Rangelands Information System (ACRIS) Management Committee. Alice Springs: Australian Government.

Maczko, K., J.A. Tanaka, R. Breckenridge, L. Hidinger, H.T. Heintz, W.E. Fox, U.P. Kreuter, C.S. Duke, J.E. Mitchell, and D.W. McCollum. 2011. Rangeland ecosystem goods and services: Values and evaluation of opportunities for ranchers and land managers. Rangelands 33 (5): 30-36.

Magill, A.W. 1989. Monitoring environmental change with color slides. Gen. Tech Rep. PSW-117, 55. Berkeley, CA: Pacific Southwest Forest and Range Experiment Station, Forest Service, U.S. Department of Agriculture.

Mansour, K., O. Mutanga, T. Everson, and E. Adam. 2012. Discriminating indicator grass species for rangeland degradation assessment using hyperspectral data resampled to AISA Eagle resolution. ISPRS Journal of Photogrammetry and Remote Sensing 70: 56-65.

Mas, J.F. 1999. Monitoring land-cover changes: A comparison of change detection techniques. International Journal of Remote Sensing 20 (1): 139-152.

Masocha, M., and A.K. Skidmore. 2011. Integrating conventional classifiers with a GIS expert system to increase the accuracy of invasive species mapping. International Journal of Applied Earth Observation and Geoinformation 13 (3): 487-494.

Mitchell, J.E. 2000. Rangeland resource trends in the United States: A technical document supporting the 2000 USDA Forest Service RPA Assessment. Gen. Tech. Rep. RMRS-GTR-68, 68. Fort Collins, CO: US Department of Agriculture, Forest Service, Rocky Mountain Research Station. 84.

Mnsur, S., and I.D. Rotherham. 2010. Using TM and ETM+ data to determine land cover land use changes in the Libyan Al-jabal Alakhdar region. In End of tradition? Part 2 commons: Current management and problems (cultural severance and commons present), landscape archaeology and ecology, ed. I.D. Rotherham, M. Agnoletti, and C. Handley, vol. 8, 32-38.

Nasr, M. 2004. Prospects for Desertification Impacts for Egypt and Libya. In Environmental Challenges in the Mediterranean 2000-2050. ed. Marquina A. NATO Science Series (Series IV: Earth and Environmental Sciences), vol 37. Springer, Dordrecht.
Naylor, B.., B.A. Endress, and C.G. Parks. 2005. Multiscale detection of sulfur cinquefoil using aerial photography. Rangeland Ecology \& Management 58 (5): 447-451.

Neely, C., Running, S. and Wilkes, A. 2009. Review of evidence on drylands pastoral systems and climate change: Implications and opportunities for mitigation and adaptation. Land and Water Discussion Paper (No. 8):viii + 38 pp.

Nefzaoui, A., Elloumi, M. and Nasr, N. 2002. Rangeland management options and individual and community strategies of agro-pastoralists in Central and Southern Tunisia. International conference on policy and institutional options for the management of rangelands in dry areas. Workshop summary paper. CAPRi Working Paper.

Oba, G., and D. Kotile. 2001. Assessments of landscape level degradation in southern Ethiopia: Pastoralists versus ecologists. Land Degradation \& Development 12 (5): 461-475.

Oldeland, J., W. Dorigo, D. Wesuls, and N. Jürgens. 2010. Mapping bush encroaching species by seasonal differences in hyperspectral imagery. Remote Sensing 2 (6): 1416-1438.

Olorunfemi, J. 1983. Monitoring urban land use in developing countries - an aerial photographic approach. Environment International 9 (1): 27-32.

Omar Al Mukhtar University. 2005. Study and evaluation natural vegetation in Al Jabal Al Akhdar area, final report. Al Bayda. (in Arabic).

Parker Williams, A.E., and E.R. Hunt Jr. 2004. Accuracy assessment for detection of leafy spurge with hyperspectral imagery. Journal of Range Management 57 (1): 106-112.

Pech, R.P., R. Graetz, and A. Davis. 1986. Reflectance modelling and the derivation of vegetation indices for an Australian semi-arid shrubland. International Journal of Remote Sensing 7 (3): 389-403.

Pickup, G., G. Bastin, and V. Chewings. 1998. Identifying trends in land degradation in non-equilibrium rangelands. Journal of Applied Ecology 35 (3): 365-377.

Prince, S., I. Becker-Reshef, and K. Rishmawi. 2009. Detection and mapping of long-term land degradation using local net production scaling: Application to Zimbabwe. Remote Sensing of Environment 113 (5): 1046-1057.

Prince, S., and C. Tucker. 1986. Satellite remote sensing of rangelands in Botswana II. NOAA AVHRR and herbaceous vegetation. International Journal of Remote Sensing 7 (11): 1555-1570.

Purevdorj, T., R. Tateishi, T. Ishiyama, and Y. Honda. 1998. Relationships between percent vegetation cover and vegetation indices. International Journal of Remote Sensing 19 (18): 3519-3535.

Rangeland Development Project. 2008. Seasonal report 2004-2008. Tripoli: Libyan Ministry of Agriculture, Livestock, and Marine. (in Arabic).

Reed, M., and A. Dougill. 2010. Linking degradation assessment to sustainable land management: A decision support system for Kalahari pastoralists. Journal of Arid Environments 74 (1): 149-155.

Reeves, M., R.A. Washington-Allen, J. Angerer, E.R. Hunt, R.W. Kulawardhana, L. Kumar, T. Loboda, T. Loveland, G. Metternicht, and R.D. Ramsey. 2015. Global view of remote sensing of rangelands: Evolution, applications, future pathways [chapter 10]. In Land resources monitoring, modeling, and mapping with remote sensing, 237-276. Boca Raton, FL: CRC Press/Taylor and Francis Group.

Reeves, M.C., M. Zhao, and S.W. Running. 2006. Applying improved estimates of MODIS productivity to characterize grassland vegetation dynamics. Rangeland Ecology \& Management 59 (1): 1-10.

Ren, H., G. Zhou, and X. Zhang. 2011. Estimation of green aboveground biomass of desert steppe in Inner Mongolia based on red-edge reflectance curve area method. Biosystems Engineering 109 (4): 385-395.

Roujean, J.L., and F.M. Breon. 1995. Estimating PAR absorbed by vegetation from bidirectional reflectance measurements. Remote Sensing of Environment 51 (3): $375-384$

Rouse, J. H., Schell, J. A. and Deering, D. W. 1973. Monitoring vegetation system in the Great Plains with ERTS. Proceedings of the Third ERTS Symposium, Goddard Space Flight Center, December, 1973.

Sankey, T.T., N. Glenn, S. Ehinger, A. Boehm, and S. Hardegree. 2010. Characterizing western juniper expansion via a fusion of Landsat 5 Thematic Mapper and lidar data. Rangeland Ecology \& Management 63 (5): 514-523.

Sant, E.D., G.E. Simonds, R.D. Ramsey, and R.T. Larsen. 2014. Assessment of sagebrush cover using remote sensing at multiple spatial and temporal scales. Ecological Indicators 43: 297-305.

Secretariat of the Convention on Biological Diversity (SCBD). 2010. Pastoralism, nature conservation and development: A good practice guide, Convention on Biological Diversity (CBD) 43. Montreal.

Serneels, S., M. Said, and E. Lambin. 2001. Land cover changes around a major east African wildlife reserve: The Mara Ecosystem (Kenya). International Journal of Remote Sensing 22 (17): 3397-3420. 
Serra, P., X. Pons, and D. Sauri. 2003. Post-classification change detection with data from different sensors: Some accuracy considerations. International Journal of Remote Sensing 24 (16): 3311-3340.

Shoshany, M., and N. Goldshleger. 2002. Land-use and population density changes in Israel - 1950 to 1990: Analysis of regional and local trends. Land Use Policy 19 (2): 123-133.

Sidahmed, A. and Yazman, J. 1994. Livestock production and the environment in lesser developed countries. Proceedings of the International Telecomputer Conference on Perspectives on Livestock Research and Development in Lesser Developed Countries, IDRC, INFORUM, Winrock international, November 1992-April 1993.

Sidahmed, A.E. 1992. Sustainable rangelands in the near East and North Africa. Rangelands: 14(4):201-205.

Solomon, B.T. 2003. Rangeland evaluation and perceptions of the pastoralists in the Borana zone of southern Ethiopia. PhD, University of the Free State.

SOS. 2009. Planning with uncertainty: Using scenario planning with African pastoralists. London: SOS Sahel International UK

Squires, V.R. 2010. People in rangelands: Their role and influence on rangeland utilization and sustainable management. In Range and animal sciences and resources management, ed. V.R. Squires, 408 Encyclopedia of Life Support Systems.

Starks, P.J., B.C. Venuto, J.A. Eckroat, and T. Lucas. 2011. Measuring eastern red cedar (Juniperus virginiana L.) mass with the use of satellite imagery. Rangeland Ecology \& Management 64 (2): 178-186.

Svoray, T., A. Perevolotsky, and P.M. Atkinson. 2013. Ecological sustainability in rangelands: The contribution of remote sensing. International Journal of Remote Sensing 34 (17): 6216-6242.

SWECO (Swedish Consultant) 1986. Final report, land survey, mapping and pasture survey for 250.000 hectares of South Jabel el Akhdar area, for Socialist People's Libyan Arab Jamahiriya Secretariat for Agricultural Reclamation and Land Development, contract no. 17/90/81. Libya.

Taha, E.A., and R.E. Khidr. 2011. Rangeland management and animal production sustainability under arid and semi arid conditions: Egypt overview. In Economic, social and environmental sustainability in sheep and goat production systems, ed. A. Bernués, J.P. Boutonnet, I. Casasús, M. Chentouf, D. Gabiña, M. Joy, A. López-Francos, P. Morand-Fehr, and F. Pacheco, 317-322. Zaragoza: CIHEAM / FAO / CITA-DGA.

Todd, S., R. Hoffer, and D. Milchunas. 1998. Biomass estimation on grazed and ungrazed rangelands using spectral indices. International Journal of Remote Sensing 19 (3): 427-438.

Tripathy, G., T. Ghosh, and S. Shah. 1996. Monitoring of desertification process in Karnataka state of India using multi-temporal remote sensing and ancillary information using GIS. International Journal of Remote Sensing 17 (12): 2243-2257.

Tucker, C., and P. Sellers. 1986. Satellite remote sensing of primary production. International Journal of Remote Sensing 7 (11): 1395-1416.

Tucker, C., C. Vanpraet, E. Boerwinkel, and E.A. Gaston. 1983. Satellite remote sensing of total dry matter production in the Senegalese Sahel. Remote Sensing of Environment 13 (6): 461-474

Tucker, C.J. 1980. Remote sensing of leaf water content in the near infrared. Remote Sensing of Environment 10 (1): 23-32.

UN DESA 2015. World population prospects: The 2015 revision, key findings and advance tables. United Nations Department of Economic and Social Affairs, Population Division working paper no. ESA/P/WP. 241

Ustin, S.L., P.G. Valko, S.C. Kefauver, M.J. Santos, J.F. Zimpfer, and S.D. Smith. 2009. Remote sensing of biological soil crust under simulated climate change manipulations in the Mojave Desert. Remote Sensing of Environment 113 (2): 317-328.

Vogelmann, J.E., G. Xian, C. Homer, and B. Tolk. 2012. Monitoring gradual ecosystem change using Landsat time series analyses: Case studies in selected forest and rangeland ecosystems. Remote Sensing of Environment 122: 92-105.

Wallace, O.C., J. Qi, P. Heilma, and R.C. Marsett. 2003. Remote sensing for cover change assessment in southeast Arizona. Journal of Range Management: 402-409.

Washington-Allen, R.A., N.E. West, R.D. Ramsey, and R.A. Efroymson. 2006. A protocol for retrospective remote sensing-based ecological monitoring of rangelands. Rangeland Ecology \& Management 59 (1): 19-29.

Weber, G.E., K. Moloney, and F. Jeltsch. 2000. Simulated long-term vegetation response to alternative stocking strategies in savanna rangelands. Plant Ecology 150 (1-2): 77-96.
Wessels, K.J., S. Prince, J. Malherbe, J. Small, P. Frost, and D. VanZyl. 2007. Can human-induced land degradation be distinguished from the effects of rainfall variability? A case study in South Africa. Journal of Arid Environments 68 (2): $271-297$.

West, N.E. 2003. Theoretical underpinnings of rangeland monitoring. Arid Land Research and Management 17 (4): 333-346.

Williams, A.P., and E.R. Hunt Jr. 2002. Estimation of leafy spurge cover from hyperspectral imagery using mixture tuned matched filtering. Remote Sensing of Environment 82 (2-3): 446-456.

WISP (World Initiative for Sustainable Pastoralism) 2008. Sustainable pastoralism moving forward with appropriate policies. WISP Policy Note No. 9.

Wittich, K., and O. Hansing. 1995. Area-averaged vegetative cover fraction estimated from satellite data. International Journal of Biometeorology 38 (4): 209-215.

Wu, W. 2009. Monitoring land degradation in drylands by remote sensing. In Desertification and risk analysis using high and medium resolution satellite data, ed. Marini, A., Talbi, M. NATO Science for Peace and Security Series C: Environmental Security. Springer, Dordrecht. 157-170.

Wulder, M.A., J.C. White, S.N. Goward, J.G. Masek, J.R. Irons, M. Herold, W.B. Cohen, T.R. Loveland, and C.E. Woodcock. 2008. Landsat continuity: Issues and opportunities for land cover monitoring. Remote Sensing of Environment 112 (3): 955-969.

Yool, S.R., M.J. Makaio, and J.M. Watts. 1997. Techniques for computer-assisted mapping of rangeland change. Journal of Range Management 50(3): 307-314

Yu, L., L. Zhou, W. Liu, and H.-K. Zhou. 2010. Using remote sensing and GIS technologies to estimate grass yield and livestock carrying capacity of alpine grasslands in Golog Prefecture, China. Pedosphere 20 (3): 342-351. https://doi.org/10.1016/S1002-0160(10)60023-9.

Zhong, J., and R. Wang. 2006. Multi-temporal remote sensing change detection based on independent component analysis. International Journal of Remote Sensing 27 (10): 2055-2061.

Zhou, Q., B. Li, and A. Kurban. 2008. Trajectory analysis of land cover change in arid environment of China. International Journal of Remote Sensing 29 (4): 1093-1107.

\section{Submit your manuscript to a SpringerOpen ${ }^{\circ}$ journal and benefit from:}

- Convenient online submission

- Rigorous peer review

- Open access: articles freely available online

- High visibility within the field

Retaining the copyright to your article

Submit your next manuscript at $>$ springeropen.com 